\title{
Some physical properties of mursh developed on limnic limestones in NW Poland
}

\begin{abstract}
Post-bog soils developed on carbonate sediments are closely related to a young-glacial landscape and postglacial lakes. Drainage of biogenic accumulation area leads to a series of transformations in accumulated formations, including the process of decession. The studies conducted in the years 2009-2012 were focused on post-bog soils near lakes: Strzeszowskie, Sitno and Drawskie in Western Pomerania. The examined soils belong to murshic soils and gleysols (The classification of Polish soils). Mursh horizons contained from 0.2 to $43.3 \%$ of carbonate and from 27.2 to $77.6 \%$ of non-carbonates fractions (Ncf), and varying amount of organic matter depending on the degree of mineralisation. Specific density of surface horizons was in the range from 1.76 to 2.33 $\mathrm{Mg} \cdot \mathrm{m}^{-3}$, and bulk density from 0.28 to $0.68 \mathrm{Mg} \cdot \mathrm{m}^{-3}$. Higher porosity was found in mursh organic soils in comparison to gleysols. The studies showed that the content of carbonate fraction was related with specific density, bulk density, porosity and water capacity. Obtained results of physical and physico-chemical analysis indicate that dewatering depth of post-bog soils developed on limnic limestone are reflected in worsened water retention properties and reduced capillary ascent in the upper layers of carbonate formations of gleysols.
\end{abstract}

Keywords: Mursh, post-bog soils, gleysols, dewatering

\section{INTRODUCTION}

About $4 \%$ of Poland's area, that is ca $12110 \mathrm{~km}^{2}$, are covered with peatlands, and $84 \%$ of that area have been transformed as a result of changes in water relations, mainly due to groundwater lowering (Piaścik and Gotkiewicz 2004, Kiryluk 2014). In Western Pomerania, where peatlands occupy $6.6 \%$ of total area, as many as 10087 out of 16266 peatland sites occur on gyttja deposits, which indicates a close relationship of these areas with the evolution of inland water bodies (Markowski 1986, Meller 2006). A considerable amount of gyttja in this region constitutes limestone deposits. These deposits are characteristic of the young-glacial landscape developed from the Vistulian formations containing $\mathrm{CaCO}_{3}$, such as silt or boulder clay (Olkowski 1967, Prusinkiewicz and Noryśkiewicz 1975, Uggla 1976, Kelts and Hsü 1978, Meller 2006). Natural succession of inland water bodies related to filling in littoral zone with carbonate sediments led to their shallowing and enabled the sedentation of peat organic matter (Meller 2006, Lemkowska 2013, Jarnuszewski 2016). Lowering of groundwater level caused by agricultural use of the area leads to the interruption of peat formation process and the transformation of peat into mursh. Increase in oxygen diffusion intensifies mineralisation of organic formations and is the cause of visible changes in morphology, structure as well as physical, chemical and biological transformations defined as the mursh-forming process (Okruszko 1992, Piaścik and Gotkiewicz 2004, Kiryluk 2009, Dawson et al. 2010, Gnatowski et al. 2010, Kechavarzi et al. 2010, Huat et al. 2011, Verry et al. 2011). Physical properties are among the main indicators of the degree of degradation of organic formations. They significantly affect water retention capacity and cover nutrient and water requirements of plants (Uggla 1969, Olkowski 1971, Marcinek and Spychalski 1998, Collins and Kuehl 2001, Meller 2006, Dawson et al. 2010, Gnatowski et al. 2010, Kiryluk 2014, Könönen et al. 2015). In the case of shallow post-bog areas, the change in hydrological conditions has an unfavourable influence on the properties of limnic deposits. Carbonate gyttjas are characterised by a high total and capillary porosity and low air porosity. However, overdrying and compaction of the upper layers reduces their total and capillary porosity (Uggla 1969, Meller 2006, Jarnuszewski 2016). In addition, an excessive overdrying of carbonate gyttja can cause colloid shrinking, whose coagulation is to a great extent irreversible, which additionally can inhibit retention capacity and upward water movement contributing to their further degradation (Markowski 1971, Meller 2006). In drained shallow organogenic 
soils, morphological organic layers are especially dynamically differentiated. Progressive mineralisation results in formation of soddy (M1), sub-soddy (M2) and transitional (M3) mursh horizons. Owing to an intensive process of humification and the activity of soil fauna in shallow organic formations, physical and chemical properties are more distinctly determined by an increasing contribution of carbonate sediments (Olkowski 1967, Uggla 1968, Okruszko 1988, Krzywonos 1993, Marcinek and Spychalski 1998, Meller 2006). Mursh has a prismatic structure in transitional sub-layer, and grained or powdery structure in surface soddy sub-layer. During mursh-forming process there is a secondary humification of organic matter, reduction of cation exchange capacity, denaturation of organic colloids, decrease in water retention and capillary capacity. However, infiltration and percolation increase, especially in shallow organic soils (Uggla 1968, 1976; Krzywonos 1993, Piaścik and Gotkiewicz 2004, Marcinek and Spychalski 1998, Meller 2006). Dynamics of mursh-forming process and its advancement are affected by the conditions and duration of dewatering, relief, type of deposit and climatic conditions, including frost occurence (Zawadzki 1957, Marcinek and Spychalski 1998, Piaścik and Gotkiewicz 2004, Bieniek and Grabowski 2007).

The aim of this paper was to determine the specific and bulk density, total and air porosity, actual and capillary water capacity of murshes developed on limnic limestone representing limni-murshic soils and murshic gleysols.

\section{MATERIALS AND METHODS}

The studies were conducted in the years 20092012 on shallow mursh lying on limnic calcareous deposits from $0.23 \mathrm{~m}$ to over $2.50 \mathrm{~m}$ thick. Soil profiles were studied near lake Sitno (site 1) and Strzeszowskie (site 2) situated within Myślibórz Lakeland and close to lake Drawsko (site 3) in the Drawskie Lakeland, in Western Pomerania (Fig. 1) (Kondracki 2001). Site 1 was located on the plain covered by biogenic sediments of a post-glacial stagnant lake, surrounded with a rolling moraine upland made of sand, gravel and boulder clay. Site 2 was in a subglacial valley of the Tywa river filled with sand and organic material. This valley cuts a morphologically diversified moraine upland made of sand and boulder clay. Site 3 was situated in the subglacial trough of lake Drawsko, a part of a larger complex of the so-called marginal trough revealed after the retreat of glacial cover of the Leszno-Poznan phase, filled with clay and sand in a few places (Kłysz 2001, Lewandowski and Nita 2008). Chosen objects were used as meadows or left

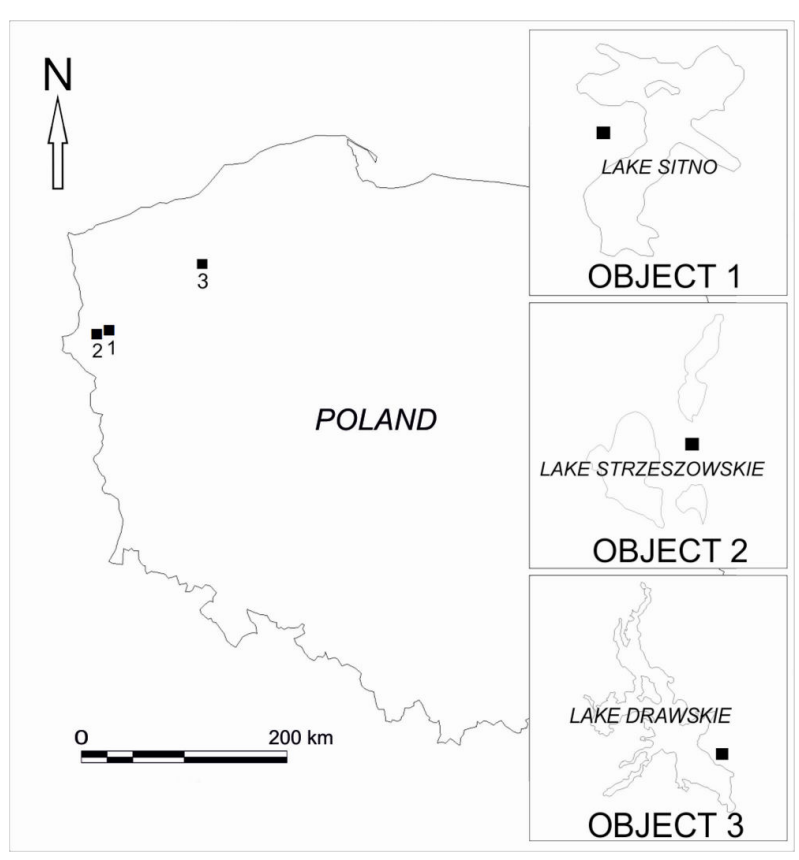

FIGURE 1. Location of the study area

as fallows with groundwater to the depth of $1 \mathrm{~m}$ below ground. During the study 9 soil profiles were analyzed, 4 of which (object 1 and 2) represented according to Polish Soil Classification (2011) and Świtoniak et al. (2016) the type - murshic soils (gleby organiczne murszowe), sub-type limni-murshic soils (gleby limnowo-murszowe), and according to IUSS Working Group WRB (2015) Drainic Histosols (Calcaric, Limnic) (Kabała et al. 2016). The remaining 5 profiles (object 2 and 3) were classified according to Polish Soil Classification (2011) and Świtoniak et al. (2016) as gleysols (gleby glejowe), sub-type murshic gleysols (gleby murszowo-glejowe), and according to WRB (IUSS Working Group WRB 2015) as Histic Gleysols (Murshic) (Kabała et al. 2016). Mean groundwater levels measured in the years 2010-2011 by piezometers installed near the soil profiles were: $58 \mathrm{~cm}$ below ground for murshic soils and $80.5 \mathrm{~cm}$ below ground for gleysols.

From particular soil profiles, 25 samples of mursh and 9 samples of calcareous sediment, lying directly under organic layers were collected. The following parameters were determined in the laboratory: loss on ignition (LOI) by burning soil material in a muffle stove at the temperature of $550^{\circ} \mathrm{C}$, soil reaction $(\mathrm{pH}$ in $\mathrm{KCl}$ at the concentration $1 \mathrm{~mol} \cdot \mathrm{dm}^{-3}$ and $\mathrm{pH}$ in $\mathrm{H}_{2} \mathrm{O}$ ) potentiometrically. In soil samples, the content of $\mathrm{CaCO}_{3}$ was determined by the Scheibler's volumetric method whereas, organic carbon (Corg) by method of Alten for organic layers or by Tiurin's method for mineral layers. Total nitrogen content (Ntot) was 
determined by means of elementary analyser COSTECH ECS 4010. Soil samples were analysed for specific density by picnometric method, bulk density, actual (sample-time) and capillary water capacity by drying and weighing method. Total porosity was estimated on the basis of specific density and bulk density. Non-capillary porosity was calculated on the basis of total porosity and water capillary capacity and corresponded to the volume of macropores.

\section{RESULTS AND DISCUSSION}

Examined mursh soils were characterised by an advanced degree of humification - Mt III and were composed of: soddy (M1), sub-soddy (M2) and transitional (M3) horizons (Okruszko 1988). Soddy horizon (M1) had a grain or powder structure, loose or very loose because of numerous roots of grasses. Horizon M2 was generally grained and more compacted. Transitional horizon (M3) was of prismatic structure, with visible vertical cracks with traces of illuvial displacement of humus and iron depletion forming rusty blotches characteristic of peat formations undergoing the process of mineralisation (Piaścik and Bieniek 2001, Sowiński and Lemkowska 2008, Jarnuszewski 2015). Colour of particular horizons depended on a high content of organic matter (Thomson and Bell 2001, Meller 2006). According to Munsell (1954) colour system the fresh samples of mursh horizons were black, of the hue 10YR rarely 7.5YR and value (lightness) 1.7 or 2 and chroma 1.Under air-dried conditions the hue was predominantly $10 \mathrm{YR}$ sporadically $2.5 \mathrm{Y}$ or $7.5 \mathrm{YR}$, value from 1.7 to 3 and chroma from 1 to 3 . The presence of calcium carbonates increased brightness in dried mursh. Below the mursh horizon there were carbonate formations $(\mathrm{Lm})$, mostly lacustrine chalk, which was either plastic or compact depending on the degree of water saturation. Carbonate formations were as a rule, yellow, of the hue $2.5 \mathrm{Y}$, $5 \mathrm{Y}$ and $7.5 \mathrm{Y}$ or yellow-red $10 \mathrm{YR}$, of high degree of value from 5 do 8 and varying chroma (1-6). Numerous channels exhibiting the activity of soil fauna (often filled with mursh) and iron precipitate spots along post-root channels in the form of mosaic or mottles were characteristic features of carbonate formations (Krzywonos 1993, Meller 2006). Occasionally, illuvial displacement of organic matter was observed (Krzywonos 1993, Meller 2004, 2006). The mursh horizon of murshic soils contained less $\mathrm{CaCO}_{3}$, as well as, fewer mineral lime-free parts and apparently a higher content of organic matter in comparison with gleysols (Table 1). Observed stratification of mursh horizon, the loss of organic matter and the increased impact of underlying deposits on the properties of mursh are typical features of degradation processes related to water table lowering (Uggla 1968, Marcinek and Spychalski 1998, Piaścik and Gotkiewicz 2004, Meller 2006, Bieniek and Grabowski 2007, Verry et al. 2011). Mursh soils under study, had neutral reaction, whereas limnic deposits - alkaline, which did not distinguish them from other post-bog soils developed from carbonate sediments (Uggla 1976, Sowiński and Lemkowska 2008, Łachacz et al. 2009). A higher value of LOI in the mursh of organic soils was accompanied by a higher content of Corg $-187.1 \mathrm{~g} \cdot \mathrm{kg}^{-1}$ in the surface layers of mursh soils compared to gley soils -143.4 $\mathrm{g} \cdot \mathrm{kg}^{-1}$ (Table 1). The values of Corg in investigated soils were slightly higher than the results obtained for similar formations by Meller $(2004,2006)$ near Miedwie lake and Sowiński and Lemkowska (2008) on the Olsztyńskie Lakeland. On the other hand Uggla (1968) and Lachacz et al. (2009) on the Mazurskie Lakeland and Mendyk and Markiewicz (2013) on the Brodnickie Lakeland found a slightly higher amounts of Corg. Deeper drained mursh of gleysols contained less total nitrogen: with a mean of $14.2 \mathrm{~g} \cdot \mathrm{kg}^{-1}$ than mursh horizons of organic soils $\left(18.1 \mathrm{~g} \cdot \mathrm{kg}^{-1}\right)$. Analysed mursh soils were characterised by a vertical differentiation of properties connected with an increase in the content of organic matter, organic carbon and total nitrogen with depth (Meller 2006, Bieniek and Grabowski 2007, Kechavarzi et al. 2010). In the studied mursh, significant differences in $\mathrm{C} / \mathrm{N}$ ratio have not been detected and the obtained values showed that there were favourable conditions for an intense microbiological activity and organic matter alterations in the process of mineralisation and humification (Kalembasa and Becher 2009). C/N ratio in examined mursh horizons was narrowing with the loss of organic matter and the increase of nitrogen in humus compounds of mursh formations undergoing a process of decession (Lachacz et al. 2009, Brouns et al. 2014).

Mursh horizons of gleysols had a higher mean specific density $\left(2.15 \mathrm{Mg} \cdot \mathrm{m}^{-3}\right)$ and bulk density $(0.539$ $\left.\mathrm{Mg} \cdot \mathrm{m}^{-3}\right)$ in comparison with murshic soils $(2.07$ and $\left.0.441 \mathrm{Mg} \cdot \mathrm{m}^{-3}\right)$, respectively. These differences were caused by a more advanced degree of mineralisation and the changes in the contribution of particular constituents of the solid phase (Marcinek and Spychalski 1998, Kechavarzi et al. 2010, Verry et al. 2011, Huat et al 2011). The loss of organic matter in the mursh horizons had a significant impact on the increase of specific and bulk density (Table 1 and 2), which has been confirmed by other studies on drained peatlands (Olkowski 1971, Krzywonos 1993, Marcinek and Spychalski 1998, Meller 2006, Verry et al. 


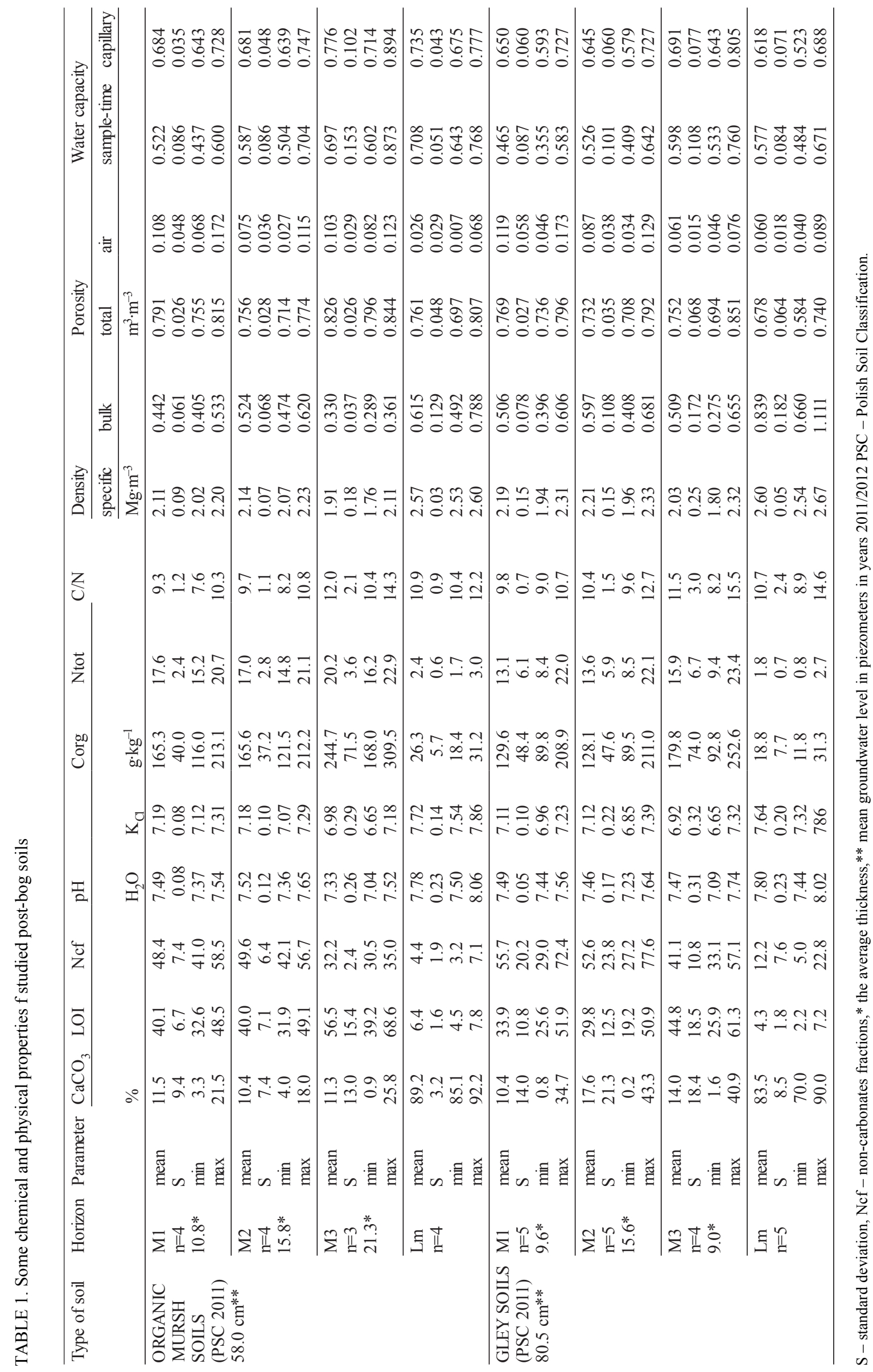


2011, Wallor and Zeitz 2016). Both, specific and bulk density in the mursh of organic soil were strongly depended on the contribution of Ncf with correlation coefficients of 0.86 and 0.89 , respectively. The role of mineral parts for total and bulk density in the process of mursh formation drew the attention of Zawadzki (1957), Uggla (1968), Krzywonos (1993) and Meller (2006). They revealed the increase in total and bulk density of mursh developed from limnic limestone under the influence of growing share of Ncf and carbonates. Kiryluk (2009) emphasises the role of mineral deposition in M1 horizon due to wind erosion and their effects on the density of mursh surface layers. Bulk density in the analyzed surface horizons increased with the increase od specific density (Table 1, 2). Apart from the effects of inorganic components, bulk density was affected by the change of structure and secondary humification of organic matter (Zawadzki 1957, Meller 2006, Dawson et al. 2010, Kechavarzi et al. 2010, Huat et al. 2011, Könönen et al. 2015). In the presented study, the surface mursh horizons density levels were similar to those of the mursh horizons of the Mazurskie Lakeland (Olkowski 1967, 1971). Organogenic horizons near Miedwie lake (Krzywonos 1993, Meller 2006) had lower bulk density values but higher in the case of the Odra valley (Marcinek and Spychalski 1998). In peat undergoing the process of mursh formation, a vertical differentiation of bulk density occurs. LOI was at similar level in horizons M1 and M2, and the lower bulk density in horizon M1 resulted by the loosening caused by the roots, the influence of soil fauna and climat factors. The lowest values of bulk density were found in horizon M3 (Table 1) which may be attributed to the smaller contribution of $\mathrm{CaCO}_{3}$ and $\mathrm{Ncf}$. Horizon M3 of organic soils turned out to have the lowest bulk density value $\left(0.330 \mathrm{Mg} \cdot \mathrm{m}^{-3}\right)$ resulting from higher saturation with water and greater degree of solid phase dispersion (Olkowski 1971, Huat et al. 2011, Verry et al. 2011). Bulk density of horizon M3 in gleysols was $0.509 \mathrm{Mg} \cdot \mathrm{m}^{-3}$, similarly to that one of horizon M1. In both types of soils, the highest bulk density was found in sub-soddy horizon M2 $\left(0.524 \mathrm{Mg} \cdot \mathrm{m}^{-3}\right.$ in organic mursh soils and $0.597 \mathrm{Mg} \cdot \mathrm{m}^{-3}$ in gley soils). This may be explained by formation of grains of this mursh layer from compacted humus. Another reason may be leaching of organic matter into free spaces during the process of humification which leads to reduction of soil porosity (Okruszko 1988, Könönen et al. 2015). In this study, total porosity (Table 1) in subhorizon M2 was lower than in other sub-horizons, and the lowest air porosity in subsoddy horizon $(9.9 \%)$ supports the above statements. Carbonate formations of similar specific density differed in bulk density depending on the degree of saturation with water and the ability of limnic limestone to swelling when waterlogged (Table1). Carbonate deposits underlying murshic soils had a distinctly lower bulk density $\left(0.615 \mathrm{Mg} \cdot \mathrm{m}^{-3}\right)$ than less saturated with water, carbonate deposits of gleysols. Ovedrying of upper layers of limnic limestone caused their compaction as a result of colloid denaturation, shrinking and subsidence of drained layers (Olkowski 1967, Meller 2006, Mendyk and Markiewicz 2013, Jarnuszewski 2016). Examined mursh soils were characterised by a high total porosity, higher than those obtained for similar formations near lake Miedwie (Krzywonos 1993, Meller 2004, 2006) and

TABLE 2. Correlation coefficients ( $r$ ) of linear regression between the properties in mursh horizons of studied soils

\begin{tabular}{|c|c|c|c|c|c|c|c|c|c|}
\hline Type of soil & & LOI & Ncf & $\begin{array}{l}\text { Specific } \\
\text { density }\end{array}$ & $\begin{array}{l}\text { Bulk } \\
\text { density }\end{array}$ & $\begin{array}{l}\text { Total } \\
\text { porosity }\end{array}$ & $\begin{array}{l}\text { Air } \\
\text { porosity }\end{array}$ & $\begin{array}{l}\text { Sample- } \\
\text { time water } \\
\text { capacity }\end{array}$ & $\begin{array}{l}\text { Capillary } \\
\text { water } \\
\text { capacity }\end{array}$ \\
\hline $\begin{array}{l}\text { ORGANIC } \\
\text { MURSH } \\
\text { SOILS } \\
(\text { PSC 2011) } \\
n=10\end{array}$ & $\begin{array}{l}\mathrm{CaCO}_{3} \\
\text { LOI } \\
\text { Ncf } \\
\text { Specific density } \\
\text { Bulk density } \\
\text { Total porosity } \\
\text { Air porosity } \\
\text { Sample-time water } \\
\text { capacity }\end{array}$ & $\begin{array}{l}0.61 \\
1.00\end{array}$ & $\begin{array}{l}-0.02 \\
-0.78 * \\
1.00\end{array}$ & $\begin{array}{c}0.48 \\
-0.98^{*} \\
0.86^{*} \\
1.00\end{array}$ & $\begin{array}{c}-0.07 \\
-0.65 * \\
0.89 * \\
0.74 * \\
1.00\end{array}$ & $\begin{array}{c}0.27 \\
0.44 \\
-0.77^{*} \\
-0.54 \\
-0.96^{*} \\
1.00\end{array}$ & $\begin{array}{r}0.07 \\
0.06 \\
-0.13 \\
0.03 \\
-0.41 \\
0.51 \\
1.00\end{array}$ & $\begin{array}{c}0.13 \\
0.13 \\
-0.28 \\
-0.20 \\
0.00 \\
-0.07 \\
-0.80 * \\
1.00\end{array}$ & $\begin{array}{c}0.19 \\
0.36 \\
-0.60 \\
-0.49 \\
-0.49 \\
0.42 \\
-0.57 \\
0.77 *\end{array}$ \\
\hline $\begin{array}{l}\text { GLEY } \\
\text { SOILS } \\
(\text { PSC 2011) } \\
n=14\end{array}$ & $\begin{array}{l}\mathrm{CaCO}_{3} \\
\text { LOI } \\
\text { Ncf } \\
\text { Specific density } \\
\text { Bulk density } \\
\text { Total porosity } \\
\text { Air porosity } \\
\text { Sample-time water } \\
\text { capacity }\end{array}$ & $\begin{array}{r}-0.26 \\
1.00\end{array}$ & $\begin{array}{c}-0.69 * \\
-0.52 \\
1.00\end{array}$ & $\begin{array}{c}0.34 \\
-0.98 * \\
0.43 \\
1.00\end{array}$ & $\begin{array}{l}0.37 \\
-0.83^{*} \\
0.30 \\
0.76^{*} \\
1.00\end{array}$ & $\begin{array}{l}-0.31 \\
0.61 \\
-0.18 \\
-0.50 \\
-0.94^{*} \\
1.00\end{array}$ & $\begin{array}{l}-0.42 \\
-0.49 \\
0.73 * \\
0.53 \\
0.17 \\
0.01 \\
1.00\end{array}$ & $\begin{array}{c}0.22 \\
0.65 * \\
-0.67 * \\
-0.63 * \\
-0.54 * \\
0.42 \\
-0.82 * \\
1.00\end{array}$ & $\begin{array}{r}0.09 \\
0.78^{*} \\
-0.66^{*} \\
-0.73^{*} \\
-0.78^{*} \\
0.69 * \\
-0.89 * \\
0.99^{*}\end{array}$ \\
\hline
\end{tabular}

* correlations significant at $\mathrm{p}<0.05, \mathrm{LOI}-$ loss-on-ignition, $\mathrm{Ncf}-$ non-carbonate fractions. 
similar to those described by Marcinek and Spychalski (1998), and Mendyk and Markiewicz (2013). Definitely higher total porosity was recorded in the mursh horizons developed from detritus gyttja on carbonate gyttja of the Mazurskie Lakeland (Olkowski 1967, Uggla 1968, 1969). Less drained mursh horizons of organic soils had a slightly higher total porosity $0.788 \mathrm{~m}^{3} \cdot \mathrm{m}^{-3}$ on average, in comparison with mursh of gleysols $-0.751 \mathrm{~m}^{3} \cdot \mathrm{m}^{-3}$. Reduction of total porosity in limni-murshic soils was significantly influenced by a percentage share of Ncf (with $\mathrm{r}=-0.77$ ), whereas in murshic gleysols this parameter significantly depended on the percentage of organic matter expressed as LOI $(\mathrm{r}=0.61)$. In the surface layers, there was a strong correlation between bulk density and total porosity in organic and gley soils with $\mathrm{r}=-0.96$ and $\mathrm{r}=-0.94$ respectively in organic soils and in gley soils (Table 2). Meller (2006) states that in shallow post-bog soils developed from limnic limestone, the increase of organic matter has a favourable impact on mursh porosity. Total porosity is reduced in the case of increase of carbonates and Ncf. Similar relationships were found by this author for sample-time and capillary water capacity. The presented studies confirm these findings only for content of organic matter and Ncf in the mursh horizon of gleysols. Krzywonos (1993) and Meller (2006) draw attention to the role of high contribution of $\mathrm{CaCO}_{3}(\geq 40 \%)$ to physical properties of mursh horizons. In studied mursh, a significant influence of $\mathrm{CaCO}_{3}$ contribution to physical properties has not been detected (Table 2). The cause was a low share of this component (on average $11.0 \%$ in limni-murshic soils and $14.0 \%$ in murshic gleysols) and a high contribution of LOI and Ncf (Table 1). In gleysol, an insignificant dependence between the increase of $\mathrm{CaCO}_{3}$ and the increase of bulk density and the decrease of total porosity was observed, and in the murshic soils an insignificant influence of $\mathrm{CaCO}_{3}$ on the increase of specific density. In the mursh horizons, the contribution of LOI (regression equation $y=-0.97 x+54.40$ in murshic solis and $y=-0.22 x+38.61$ in gleysols) and Nef (regression equation $y=-0.03 x+45.60$ in murshic soils and $y=-0.78 x+61.39$ in gleysols) had the inverse dependence in relation to the contribution of $\mathrm{CaCO}_{3}$. The highest share of macropores was observed in horizon M1 loosened with roots (mean amount of macropores was $13.65 \%$ and $15.47 \%$ of total porosity). In murshic gleysols, air porosity was reduced with the depth, and increased contribution of Ncf was related positively with the amount of macropores (with $\mathrm{r}=0.73$ ). It is worth to mention that there were also differences in non-capillary porosity between the transitional mursh $\left(0.106 \mathrm{~m}^{3} \cdot \mathrm{m}^{-3}\right)$ and underlying carbonate deposits $\left(0.026 \mathrm{~m}^{3} \cdot \mathrm{m}^{-3}\right)$. Slightly higher values of air porosity were observed in the limnic limestone of murshic gleysols $\left(0.060 \mathrm{~m}^{3} \cdot \mathrm{m}^{-3}\right)$. An increase of air porosity of calcareous sediments indicates a stronger degradation of murshic gleysols due to drainage (Lemkowska 2013). The obtained results reveal a low infiltration ability of limnic deposits compared to organic layers (Marcinek and Spychalski 1998, Meller 2004). In examined soils, the sample-time and capillary capacity in mursh horizons increased with the depth (Table 1), and higher values for these parameters were obtained in murshic soils. In gleysols, the increase of both total and capillary water capacity was affected by an increase in the content of organic matter expressed as LOI. However, in the case of percentage share of Ncf a reverse relationship was found (Table 2). Decrease of content of organic matter, humification and texture alterations distinctly worsened water conditions in the mursh horizon of gleysols. Reduction of total and capillary porosity caused by a humification process results in lowering water retention of surface layers especially the amount of plant available water (Marcinek and Spychalski 1998, Meller 2006, Kechavarzi 2010, Könönen et al. 2015). It should be mentioned that in organic soils sample-timewater capacitywas observed in limnic limestone and the mursh horizon M3, which is the evidence for the retention of moisture in organic formations due to the capillary ascent of water from carbonate formations. Murshic gleysols were deeper drained and limnic limestone more dense, which contributed to lower values for actual moisture in mursh horizons and carbonate deposits (Table 1). Moreover, in stratified organic soils capillary ascent can be interrupted because of inter-strata hydraulic resistance worsening water regime, limiting the retention of available water and may also accelerate the mineralisation of mursh horizons. However, in post-bog carbonate sediments this phenomenon is less intensive than in the case of mursh layers on sand (Krzywonos 1993, Marcinek and Spychalski 1998, Meller 2006, Lemkowska 2013). The occurrence of carbonate formations below mursh horizons distinguishes the examined formations from those developed on sand. A high capillary capacity allows the ascent of water to mursh horizons, which slows down the process of degradation. On the other hand, long-term unfavourable conditions may lead to the limitation of the above mentioned functions. Further degradation may transform the described soils into murshic soils, postmurshic soils and the last stage - mineral soils (Marcinek and Spychalski 1998, Piaścik and Gotkiewicz 2004). As a 
result, the impoverishment of biodiversity and unfavourable changes in phytocoenoses (Meller 2006, Kiryluk 2014) may occur.

\section{CONCLUSIONS}

1. Long-term deep dewatering of post-bog soils leads to: the mineralisation of organic matter in surface layers, reduction in thickness of organic formations and their densification. In examined soils deeper dewatering was found in gley soils which were also more degraded in comparison with organic soils.

2. The higher content of $\mathrm{CaCO}_{3}$ was observed in the surface horizon of gleysols then organic soils. The contribution of $\mathrm{CaCO}_{3}$ has not significantly influenced the physical properties of the studied mursh.

3. In the mursh horizons of organic soils the content of organic matter has clearly influenced its specific and bulk density, whereas in the mursh horizons of gleysols the content of organic matter has had a significant influence not only on its density, but also total porosity and water capacity. The increase in Ncf resulted in significantly higher values for specific and bulk density in organic soils and for air porosity in gleysols.

4. The effects of dewatering depth of post-bog soils developed from limnic limestone are reflected in worsened retention properties and reduced capillary ascent in the upper layers of carbonate formations of gley soils. Limnic limestone underlying the mursh of organic soils had a lower infiltration but its capillarity was high and similar to the mursh which ensured similar moisture retention to the surface layers.

\section{REFERENCES}

Bieniek A., Grabowski K., 2007. Skutki ewolucji gleb murszowych w krajobrazie sandrowym na przykładzie obiektu Głuch. Roczniki Gleboznawcze - Soil Science Annual 58(1): 5-11.

Brouns K., Verhoeven J.T.A., Hefting M.M., 2014. Short period of oxygenation releases latch on peat decomposition. Science of the Total Environment 481: 61-68.

Collins E.M., Kuehl R.J., 2001. Organic matter accumulation and organic soils. [In:] Wetland Soils Genesis, Hydrology, Landscapes and Classification (Richardson J.L., Vepraskas M.J., Editors). Lewis Publishers, Boca Raton: 137-162.

Dawson Q., Kechavarzi C., Leeds-Harrison P.B., Burton R.G.O., 2010. Subsidence and degradation of agricultural peatlands in the Fenlands of Norfolk, UK. Geoderma 154: 181-187.

Gnatowski T., Szatyłowicz J., Brandyk T., Kechavarzi C., 2010. Hydraulic properties of fen peat soils in Poland. Geoderma 154(3-4): 188-195.

Huat B.B.K., Kazemian S., Prasad A., Barghchi M., 2011. State of an art review of peat: General perspective. International Journal of the Physical Sciences 6(8): 1988-1996.

IUSS Working Group WRB, 2015. World reference base for soil resources 2014. International soil classification system for naming soils and creating legends for soil maps. Update 2015. World Soil Resources Report 106, Food and Agriculture Organization of the United Nations, Rome: 188 pp.

Jarnuszewski G., 2015. Właściwości chemiczne gleb organicznych wytworzonych na kredzie jeziornej z okolic jezior: Strzeszowskie, Sitno i Sierakowo (woj. zachodniopomorskie). Soil Science Annual 66(4): 168-179.

Jarnuszewski G., 2016. Charakterystyka wybranych fizycznych i chemicznych właściwości gleb pobagiennych wytworzonych na węglanowych osadach limnicznych w sąsiedztwie jeziora Dubie (woj. zachodniopomorskie). Soil Science Annual 64(1): 24-31.

Kabała C., Świtoniak M., Charzyński P., 2016. Correlation between the Polish Soil Classification (2011) and international soil classification system World Reference Base for Soil Resources (2015). Soil Science Annual 67(2): 88-100.

Kalembasa D., Becher M., 2009. Frakcje azotu w glebach torfowo-murszowych w dolinie górnego Liwca. Woda-Środowisko-Obszary Wiejskie 9(2): 73-82.

Kechavarzi C., Dawson Q., Leeds-Harrison P.B., 2010. Physical properties of low-lying agricultural peat soils in England. Geoderma 154: 196-202.

Kelts K., Hsü K.J., 1978. Freshwater Carbonate Sedimentation. [In:] Lakes Chemistry Geology Physics (Lerman A., Editor). Springer-Verlag, Berlin, Heidelberg, New York: 295-323.

Kiryluk A., 2009. Proces grądowienia w pobagiennych ekosystemach łąkowych. Woda-Środowisko-Obszary Wiejskie 9(4): 59-69.

Kiryluk A., 2014. Wpływ odwodnienia na fizyko-wodne właściwości gleb pobagiennych na obiekcie łąkarskim w dolinie rzeki Supraśli. Inżynieria Ekologiczna 38: 26-34

Kłysz P., 2001. Faza pomorska ostatniego zlodowacenia na Pojezierzu Drawskim. Przegląd Geograficzny 73(1-2): 3-24.

Kondracki J., 2001. Geografia regionalna Polski. Wydawnictwo Naukowe PWN, Warszawa: 441 pp.

Könönen M., Jauhiainen J., Laiho R., Kusin K., Vasander H., 2015. Physical and chemical properties of tropical peat under stabilised land uses. Mires and Peat 16: 1-13.

Krzywonos K., 1993. Organogeniczne gleby węglanowe na kredzie jeziornej. Charakterystyka i klasyfikacja. Wiadomości IMUZ 17(3): 37-55.

Lemkowska B., 2013. , Rędziny czwartorzędowe” w Systematyce gleb Polski. Soil Science Annual 64(4): 135-139.

Lewandowski J., Nita M., 2008. Ewolucja systemu hydrograficznego i szaty roślinnej dorzecza górnej Piławy i górnej Drawy (Pomorze Środkowe). Przegląd Geologiczny 56(5): 380-390.

Łachacz A., Nitkiewicz M., Pisarek W., 2009. Soil conditions and vegetation on gyttja lands in the Masurian Lakeland. Contemporary Problems of Management and Environmental Protection. Wetlands - Their Functions and Protection 2: 61-94.

Marcinek J., Spychalski M., 1998. Degradacja gleb organicznych doliny Obry po ich odwodnieniu i wieloletnim rolniczym użytkowaniu. Zeszyty Problemowe Postępu Nauk Rolniczych 460: 219-236.

Markowski S., 1971. Wstępne badania kurczliwości osadów gytii. Zeszyty Problemowe Postępów Nauk Rolniczych 107: 73-84. Markowski S., 1986. Kraina ukrytej wody - torfowiska na Po- 
morzu Zachodnim, znaczenie zagrożenie i ochrona. [W:] Materiały XIII Zjazdu Hydrobiologów Polskich, Szczecin, 123.

Meller E., 2004. Niektóre właściwości chemiczne różnie użytkowanych gleb gytiowo-murszowych w pobliżu jeziora Miedwie. Roczniki Gleboznawcze - Soil Science Annual 55(3): 139-146.

Meller E., 2006. Płytkie gleby organogeniczno-węglanowe na kredzie jeziornej i ich przeobrażenia w wyniku uprawy. Akademia Rolnicza w Szczecinie, Rozprawy 233: 1-115.

Mendyk Ł., Markiewicz M., 2013. Wpływ stopnia odwodnienia na właściwości gleb wytworzonych z osadów jeziornych. Episteme 18(3): 321-327.

Munsell soil color charts. 1954. Munsell Color Company, Inc. Baltimore.

Okruszko H., 1988. Zasady podziału gleb hydrogenicznych na rodzaje oraz łączenia rodzajów w kompleksy. Roczniki Gleboznawcze - Soil Science Annual 39(1): 127-152.

Okruszko H., 1992. Siedliska hydrogeniczne, ich specyfika i zróżnicowanie. Biblioteczka Wiadomości IMUZ 79: 5-14.

Olkowski M., 1967. Niektóre właściwości chemiczne i fizyczne gytii osuszonych jezior mazurskich. Zeszyty Naukowe WSR Olsztyn 23: 245-262.

Olkowski M., 1971. Kształtowanie się ciężaru objętościowego w glebach bagiennych i murszowych torfowisk oraz gytiowisk Pojezierza Mazurskiego. Zeszyty Naukowe WSR Olsztyn 27(801): 93-108.

Piaścik H., Bieniek B., 2001. Zmiany w zawartości form żelaza powodowane procesem murszenia w warunkach zróżnicowanego odwodnienia. Roczniki Gleboznawcze - Soil Science Annual 52: 119-125.

Piaścik H., Gotkiewicz J., 2004. Przeobrażenia odwodnionych gleb torfowych jako przyczyna ich degradacji. Roczniki Gleboznawcze - Soil Science Annual 55(2): 331-338.

Polish Soil Classification (Systematyka Gleb Polski), 2011. Roczniki Gleboznawcze - Soil Science Annual 62(3): 1-193 (in Polish with English summary).

Prusinkiewicz Z., Noryśkiewicz B., 1975. Geochemiczne i paleo-pedologiczne aspekty genezy kredy jeziornej jako skały macierzystej północnopolskich rędzin. Acta Universitatis Nicolai Copernici, Geografia 35: 115-137.

Sowiński P., Lemkowska B., 2008. Ewolucja „rędzin jeziornych” w krajobrazie Pojezierza Mazurskiego. Roczniki Gleboznawcze - Soil Science Annual 59(1): 134-140.

Świtoniak M., Kabała C., Charzyński P., 2016. Propozycja anglojęzycznych nazw jednostek Systematyki gleb Polski. Soil Science Annual 67(3): 103-116.

Thompson J.A., Bell J.C., 2001. Hydric soil indicators in mollisol landscapes. [In:] Wetland Soils Genesis, Hydrology, Landscapes and Classification (Richardson J.L., Verpaskas M.J., Editors). Lewis Publishers, Boca Raton: 371-382.

Uggla H., 1968. Bagienne i murszowe gleby gytiowiska Gązwa. Roczniki Gleboznawcze - Soil Science Annual 18(2): 369413.

Uggla H., 1969. Gleby gytiowe Pojezierza Mazurskiego. Cz. II. Właściwości fizyczne, chemiczne i biologiczne gleb gytiowobagiennych i gytiowo-murszowych. Zeszyty Naukowe WSR Olsztyn, 25(3): 583-605.

Uggla H., 1976. „Rędziny” Pojezierza Mazurskiego. Roczniki Gleboznawcze - Soil Science Annual 27 (2): 113-125.

Verry E.S., Boelter D. H., Päivänen J., Nichols D.S., Malterer T., Gafni A., 2011. Physical properties of organic soils.[In:] Peatland Biogeochemistry and Watershed Hydrology at the Marcell Experimental Forest (Kolka R., Sebestyen S., Verry E.S., Brooks K., Editors). Taylor and Francis Group, Boca Raton: $135-176$.

Wallor E., Zeitz J., 2016. How properties of differently cultivated fen soils affect grassland productivity. A broad investigation of environmental interactions in Northeast Germany. Catena 147: 288-299.

Zawadzki S., 1957. Badania genezy i ewolucji gleb błotnych węglanowych Lubelszczyzny. Annales Universitatis Mariae Curie-Skłodowska Lublin 12(1): 1-78.

Received: October 9, 2016

Accepted: August 10, 2017

Associated editor: J. Rejman

\title{
Wybrane wlaściwości fizyczne murszy wytworzonych na węglanowych osadach wapiennych w NW Polsce
}

\begin{abstract}
Streszczenie: Gleby pobagienne wytworzone na osadach węglanowych są ściśle związane z krajobrazem młodoglacjalnym i jeziorami polodowcowymi. Odwodnienie równin akumulacji biogenicznej prowadzi do serii przeobrażeń zgromadzonego materiału, włącznie z procesem decesji. Badania przeprowadzono w latach 2009-2012 na obszarach występowania gleb pobagiennych w pobliżu jezior: Strzeszowskie, Sitno i Drawskie na Pomorzu Zachodnim. Badane gleby zaliczono do gleb organicznych murszowych i gleb glejowych (według Systematyki gleb Polski). Poziomy murszowe zawierały od 0,2 do 43,3\% węglanów i od 27,2 do $77,6 \%$ mineralnych frakcji niewęglanowych, natomiast zawartość materii organicznej uzależniona była od zaawansowania procesu mineralizacji i intensywności odwodnienia. Gęstość właściwa poziomów powierzchniowych wynosiła od $1,76 \mathrm{do} 2,33 \mathrm{Mg} \cdot \mathrm{m}^{-1}$, natomiast gęstość objętościowa wahała się od 0,275 do $0,681 \mathrm{Mg} \cdot \mathrm{m}^{-1}$. Mursz gleb organicznych charakteryzowała się wyższą porowartością całkowitą $\left(0,788 \mathrm{~m}^{3} \cdot \mathrm{m}^{-1}\right)$ w porównaniu z murszem gleb glejowych. W badanych murszach stwierdzono zależność między zawartością węglanów, mineralnych frakcji niewęglanowych i materii organicznej a gęstością właściwą, objętościową, porowatością ogólną i pojemnością wodną. Uzyskane wyniki właściwości fizycznych i chemicznych wskazują także, że głębokość odwodnienia gleb pobagiennych wytworzonych na limnicznych osadach wapiennych znajdują odzwierciedlenie w pogarszających się właściwościach retencyjnych i zmniejszeniu podsiąku kapilarnego w stropowych warstwach osadów węglanowych.
\end{abstract}

Słowa kluczowe: Mursz, gleby pobagienne, wapienne osady limniczne, właściwości fizyczne 